\title{
Identification of microorganisms promoting debris flows caused by eutrophication of hillside ecosystems
}

\author{
K. Kakugawa ${ }^{1}$, T. Futagami ${ }^{1}$, M. Matsuda ${ }^{1}$, H. Sakai ${ }^{1}$, Y. Amano ${ }^{1}$, \\ Y. Fujiwara ${ }^{2}$, H. Hattori ${ }^{2} \&$ S. Sakurai ${ }^{3}$ \\ ${ }^{1}$ Hiroshima Institute of Technology, Japan \\ ${ }^{2}$ Taisei Corporation, Japan \\ ${ }^{3}$ Construction Engineering Research Institute Foundation, Japan
}

\begin{abstract}
A large number of hazards all over the world are caused by debris flows and landslides, and this is especially so every year in Japan. In June 1999, August 2005, July 2010 in the Hiroshima prefecture, and in July 2009 in the Yamaguchi prefecture, there were many hazardous occurrences of large debris flows and landslides owing to torrential downpours. Through the survey made of these hazards it seems that there are two main factors causing the increase of hazards and consequent risks. The two main factors are the contiguity of urbanization of hillsides and the bio-deterioration of mechanical structures of the ground on hillsides caused by eutrophication (nutrient enrichment). The eutrophication promotes microbial activities that deteriorate the mechanical structures of the ground on the hillside slopes. Microorganisms promote the weathering of rocks to soils and cause aggregation of soils by their metabolites. Aggregated structures of soils wet the ground to decrease the resistance to landslides. It seems that microbial activities accelerate the occurrence of debris flows. The eutrophication causes the bio-weathering of the ground. This contribution describes the investigation of the relationships between debris flows and microorganisms activated by eutrophication of hillside ecosystems in order to construct a precise model of occurrence of debris flows. The model may be able to mitigate the hazards. Identification of microorganisms in the subsurface of the hillside was obtained by using a molecular biological technique. It was observed that the values of the eutrophication index (TC and $\mathrm{TN}$ ) are high in the weathered rock and low in the unweathered rock. Thus weathering of rock can
\end{abstract}


cause the increase of the risk due geological hazards of landslides and debris flows.

Keywords: debris flow, landslide, microorganisms, eutrophication of ground, bio-deterioration of ground, molecular biological technique, DNA, Denaturing Gradient Gel Electrophoresis, DGGE, natural hazard, ecological systems, mechanical deterioration of ground, aggregated structure of soils, weathering.

\section{Introduction}

A large number of hazards all over the world are caused by debris flows and landslides, and this is especially so every year in Japan. In June 1999, August 2005, July 2010 in the Hiroshima prefecture, and in July 2009 in the Yamaguchi prefecture, there were many hazardous occurrences of large debris flows and landslides owing to torrential downpours. Through the survey made of these hazards it seems that there are two main factors causing the increase of hazards and consequent risks. The one factor is the contiguity of urbanization of hillsides and streams. The other factor is the bio-deterioration of mechanical structures of the ground on hillsides caused by eutrophication (nutrient enrichment) originating in the transition of the ecological systems on the hillsides. These two factors increase the hazards of debris flows several times over. The eutrophication promotes microbial activities that deteriorate the mechanical structures of the ground on the hillside slopes. Microorganisms promote the weathering of rocks to soils and cause aggregation of soils by their metabolites. Aggregated structures of soils wet the ground to decrease the resistance to landslides. It seems that microbial activities accelerate the occurrence of debris flows. This contribution describes the investigation of the relationships between debris flows and microorganisms activated by eutrophication of hillside ecosystems in order to construct a precise scenario model of occurrence of debris flows. The precise scenario model may be able to mitigate the hazards. Identification of microorganisms in the subsurface of the hillside was obtained by using a molecular biological technique.

Historically, a microbial community was investigated by culture-dependent methods. However this way was limited to only identifying isolated strains growing on specific nutrient media. So these data couldn't show exactly the composition of microbial community. Recently, culture-independent approaches have been used increasingly to determine the composition of complex microbial communities. These procedures have enabled the simultaneous characterisation of whole ecosystems and the identification of many species from these sources. The shift from culture-dependent assessment to culture-independent analysis has led to a revolution in microbial ecology. These techniques provide a more sensitive and rapid method than conventional culture dependent analysis with the major benefit of detecting microorganisms which are difficult to culture or uncultivable. Unfortunately, while such approaches possess numerous advantages over culture-based methods, there can still be some limitations. A number of key factors to consider when employing a culture-independent approach are described below. Culture-independent assessment most frequently 
relies on the analysis of nucleic acids isolated from an entire microbial population. DNA is the focus of analysis in the majority of such studies and provides information with respect to the bacterial diversity and over all microbial history of the environment in question.

From the Denaturing Gradient Gel Electrophoresis (DGGE) analysis it was found that there are many microorganisms in the soft slope composed of the weathered rocks and are not many in the unweathered hard slope composed of weathered rocks. Also, it was observed that the values of the eutrophication index (TC and $\mathrm{TN}$ ) are high in the soft slope and low in the hard slope. Thus the weathering promoted by eutrophication of hillside ecosystems can cause the increase of the risk due geological hazards of landslides and debris flows.

\section{Investigation on bio-deterioration in hillsides slopes}

\subsection{Investigation sites}

The filed investigation on bio-deterioration caused by the eutrophication in the hillsides slopes was conducted in the two sites of hillside slopes in Gokurakuji Hillside near Hiroshima Institute of Technology. The one site is composed of unweathered rock. The other is composed of weathered rock. The investigation subjects are the DGGE analysis, the nutrient (Total Carbon (TN) test and the strength test.

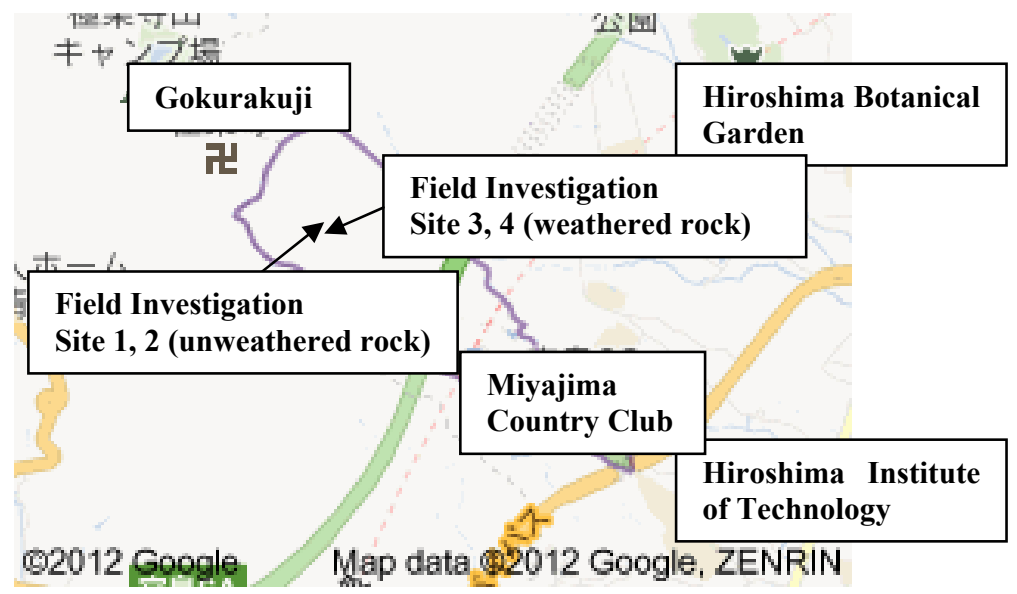

Figure 1: $\quad$ Field investigation sites in Gokurakuji hillside.

\subsection{DNA extraction}

The rock samples were crushed to pieces with a hammer. $0.5 \mathrm{~g}$ rock powder was put into a micro centrifuge tube, and $500 \mu \mathrm{l}$ of Milli-Q water was added. The micro centrifuge tube was vortexed for $5 \mathrm{~min}$. After centrifugation at $12000 \mathrm{rpm}$ for $5 \mathrm{~min}$, the supernatant was transferred to new micro centrifuge tube with 
$200 \mathrm{mg}$ of skim milk. After vortexing, microbial DNA was isolated from a mixed solution using an ISOIL for Beads Beating Kit (Nippon Gene, Toyama, Japan), according to the manufacturer's instructions.

\subsection{PCR-DGGE analysis}

For the DGGE analysis of bacterial communities, the universal bacterial PCR primer set for the 16S rRNA V3 region [341F: 5'-CCTACGGGAGGCAGCAG3' (Escherichia coli positions 341 to 357) and 907R: 5'CCGTCAATTCMTTTRAGTTT-3' (E. coli positions 907 to 926)] was used. The $341 \mathrm{~F}$ primer contained a GC clamp sequence at its 5'end: CGCCCGCCGCGCGCGGCGGGCGGGGCGGGGGCACGGGGGG. Each PCR reaction mixture $(50 \mathrm{ml})$ consisted of $1 \mu \mathrm{DNA}$ (approximately $10 \mathrm{ng}$ ), $5 \mu \mathrm{l}$ ExTaq buffer (Takara Bio, Siga, Japan), 0.25 mMeach deoxynucleoside triphosphate (Takara Bio), $25 \mathrm{p}$ mol of each primer, and 0.5 units of Ex Taq DNA polymerase (Takara Bio). The amplification program was as follows: an initial denaturing step at $95^{\circ} \mathrm{C}$ for $5 \mathrm{~min}$, followed by $94^{\circ} \mathrm{C}$ for $1 \mathrm{~min}, 64^{\circ} \mathrm{C}$ for $1 \mathrm{~min}$, and $72^{\circ} \mathrm{C}$ for $3 \mathrm{~min}$. The annealing temperature was subsequently decreased by $1{ }^{\circ} \mathrm{C} /$ cycle until it reached $56^{\circ} \mathrm{C}$, and the annealing temperature of the last 2 cycles was $55^{\circ} \mathrm{C}$. The final extension step was $72^{\circ} \mathrm{C}$ for $10 \mathrm{~min}$.

The D Code system for DGGE (Bio-Rad, Hercules, CA, USA) was used for the bacterial DGGE analysis. For the bacterial samples, $8 \%$ gradient poly-acryl amide gels with a denaturing gradient ranging from $30-60 \%$ were produced; a $100 \%$ denaturant corresponds to $7 \mathrm{M}$ urea and $40 \%$ formamide. Electrophoresis was performed at $150 \mathrm{~V}$ at $60^{\circ} \mathrm{C}$ for $6 \mathrm{~h}$. After electrophoresis, the gels were stained for 30 min with SYBR Gold (Molecular Probes, Eugene, OR, USA), and the gel image was photographed using Molecular Imager FX (Bio-Rad, Hercules, CA, USA).

\subsection{Nutrient test}

Total nitrogen (TN) by using C-N analyser was conducted for the unweathered rock and the weathered rock.

\subsection{Strength test}

The strength test was conducted for the unweathered and the weathered rock by using the Equotip Rebound Hardness Tester and Yamanaka-type Soil Hardness Tester.

\section{Results}

\subsection{PCR-DGGE analysis}

The dominant bacterial population concerning of debris flow was investigated by PCR-DGGE, using universal primers, which amplified the V3 region of the $16 \mathrm{~s}$ rDNA. Results of PCR-DGGE profiles are shown in Figure 2. The bands were 
considered to represent taxonomical units close to the species level in PCRDGGE analysis because each of them constitutes a unique DNA-sequence type, which in turn corresponds to a discrete bacterial population. As indicated in Figure 2, the banding patterns of lanes 1-2 differ from those of lanes 3-4. This result shows that the composition of microbial community is different between the unweathered rock and the weathered rock. To clarify the composition of microbial community, clone library analysis and identification of microorganisms are being carried out.

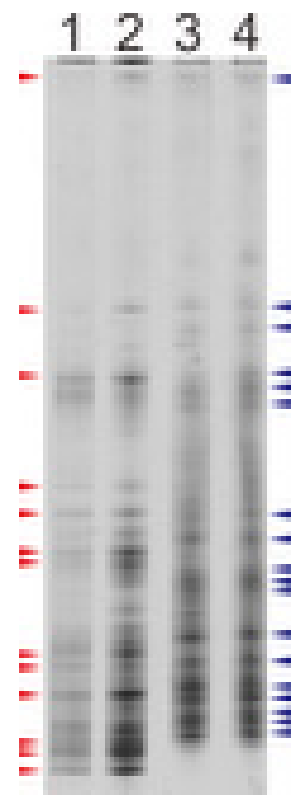

Figure 2: DGGE profile of extracted DNA.

Lanes 1-2: unweathered rock (hard rock); Lanes 3-4: weathered rock (soft rock). The triangles show represented band of DNA. The red triangles show represented the bands of lanes 1 and 2 . The blue ones show the bands of lanes 3 and 4.

\subsection{Nutrient test}

The results of nutrient test are shown in Table 1.

Table 1: $\quad$ Results of nutrient test.

\begin{tabular}{|c|c|c|l|}
\hline $\begin{array}{c}\text { Investigation } \\
\text { Site No. }\end{array}$ & $\begin{array}{c}\text { Total } \\
\text { Carbon } \\
\mathbf{( \% )}\end{array}$ & $\begin{array}{c}\text { Total } \\
\text { Nitrogen } \\
\mathbf{( \% )}\end{array}$ & Remark \\
\hline 1,2 & 0.55 & 0.05 & $\begin{array}{l}\text { Unweathered } \\
\text { rock }\end{array}$ \\
\hline 3,4 & 2.18 & 0.21 & Weathered rock \\
\hline
\end{tabular}




\subsection{Strength test}

The results of the strength test are shown in table 2 .

Table 2: $\quad$ Results of strength test.

\begin{tabular}{|c|c|c|l|}
\hline $\begin{array}{c}\text { Investigation } \\
\text { Site No. }\end{array}$ & $\begin{array}{c}\text { Ecuotip Rebound } \\
\text { Hardness Tester } \\
\text { (MPa) }\end{array}$ & $\begin{array}{c}\text { Yamanaka Type } \\
\text { Soil Hardness } \\
\text { Tester } \\
\text { (MPa) }\end{array}$ & Remark \\
\hline 1,2 & 51.25 & 50.67 & Unweathered rock \\
\hline 3,4 & 0.97 & 0.95 & Weathered rock \\
\hline
\end{tabular}

\section{Conclusions}

Through the results of the investigation on weathering promoted by eutrophication, it may be seen that where many kinds of microorganisms are found, the stability of ground formation is small and there are dangers of occurrence of debris flows. Examinations of total carbon and total nitrogen in the natural hillsides show a similar pattern. It may be well to create a "hazard map" using levels of total carbon (TC) and total nitrogen (TN) in close-to-the-surface samples to forecast future landslides causing debris flows.

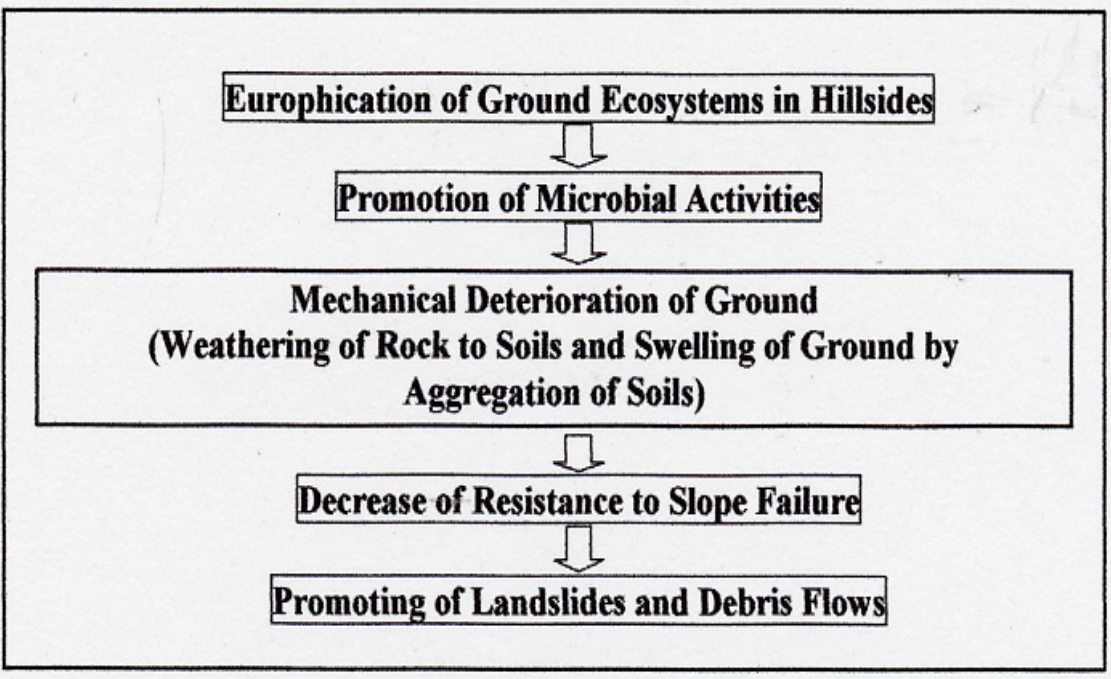

Figure 3: Scenario model of debris flow promoted by mechanical biodeterioration of ground due to eutrophication of hillside ecosystems

The results of PCR-DGGE analysis show that the compositions of microbial community are different between the unweathered rock and the weathered rock. 
Now, we are carrying out the analysis of the existence ration of microorganisms and the identification of microorganisms. We expect that these data will clarify the microorganisms concerning the rock weathering.

This paper is the first attempt to examine the DNA of microorganisms to promote debris flows due to eutrophication of the hillside ecosystems. The continuation of the research may bring a useful technique to make a precise scenario model of debris flows to avoid the risk of the hazards of the debris flows.

At this time, the microbial community was analysed by bacterial primer sets. This data only clarifies a part of complicated microbial community. If we want to know exactly the composition of microbial community, we have to use the various primer sets (ex. fungi, archaea and so on).

\section{Acknowledgement}

This work was supported by JSPS KAKENHI (Grant Number 23310129).

\section{References}

[1] Kakugawa K., Yamada K. Maeda H., Takashiba S. (2010), "Development of Real Time DNA Detection Apparatus for LAMP Method", Transactions of The Institute of Electric Engineers of Japan, C, Vol. 130(5), 807-812 (in Japanese).

[2] Futagami, T., Terauchi K., Kono T. (2010), "Transportation Phenomena of Substances in Hillside Ecosystems Promoting Debris Flows", Proceedings of 6th International Symposium on Eco-hydraulics, IAHR, Poster Session 56 (published by CD-ROM). 